\title{
CHARACTERISTICS OF COMMUNITY SUPPORTED AGRICULTURE IN THE WESTERN TRANSDANUBIA REGION
}

\author{
Károly KACZa ${ }^{\text {, Judit HEGYI }}$, Nóra GOMBKÖTÖa
}

\begin{abstract}
a Széchenyi István University, Faculty of Agricultural and Food Sciences, Department of Agricultural Economics and Rural Development, Address: 9200 Mosonmagyaróvár, Vár tér 2., e-mail: kacz.karoly@sze.hu,hegyi.judit@sze.hu, gombkoto.nora@sze.hu
\end{abstract}

Cite this article: Kacz, K., Hegyi, J., Gombkötő, N. (2019) Characteristics of community supported agriculture in the Western Transdanubia region. Deturope 11(1), 42-54.

\begin{abstract}
Both industrialization of agriculture and globalization of food trade have begun in the 20th century. Consumer habits have also undergone major changes in line with altered processes in the structure of food trade initiating merits as well as drawbacks. For instance, currently small-scale agriculture or local product supporting consumption is increasingly forced to play a marginal role all over the world. Small farmers are underrepresented in most traded venue, while production is shifting towards bigger market participants. Locally, this means that the volume of production, labour requirements and diversity of products will be reduced, consequently local characteristics will slowly disappear. As an essential requirement for such production the traditional knowledge will not be able to be passed down to forthcoming generations.

As a result of a survey, a problem and an objective tree of community supported agriculture was created. These problem/target trees were constructed after an analysis of CSA through a scrutiny of several farmer's organization and individual consumers in the Western Transdanubia region of Hungary. Followed by the evaluation of data the most influential factor, the basic problem was determined, as a consequence of which the long-term, strategic objective in terms of the market power of CSA organizations has been set forth.
\end{abstract}

Keywords: Short food supply chain, Community supported agriculture, Problem tree, Objective tree, Producer, Consumer

\section{INTRODUCTION}

The social and economic roles and the environmental impacts of agriculture are defined by two main directions regarding their goals: interpretation based on production and interpretation based on environmental management. The European agriculture policy used the interpretation based on production to improve the "industrial" agriculture in order to eliminate the food shortages after the Second World War, which made the boost of agricultural performance necessary. They used development of industrial agriculture; mechanization, pesticides and fertilizers to implement this goal, but this caused problems after a short amount of time, as it overloaded and polluted the environment (Kainer, 2007). Thus, the industrialization of agriculture and the globalization of food trade began in the second half of the 20th century. 
Changing the structure of food trade changed the consumers' habits also. This process brought numerous problems that often were not reflected in the price of the goods. For example, small scale agricultural production and consumption supporting the local products are getting overshadowed worldwide. The often unequal power relations between smaller and bigger players of the global food supply chain generate significant social tensions all across the world. The intensive, large-scale (conventional) production methods and the increased transport distances are putting a lot of weight on the environment.

Small farmers are increasingly excluded from the center of trade and production is shifting towards the larger market players. Therefore, the physical distance between the producer and the consumer increases, while many players are involved in the value chain. On a local level, it means that the quantity and the demand for personnel is decreasing, so is the diversity of products, which causes the step-by-step disappearance of local characteristics, the traditional knowledge (that is necessary for production) and the trust. Community supported agriculture (CSA), as part of short food supply chain (SFSC) system, offer a solution to these problems. They reduce the physical distance between producers and customers and - unlike long supply chains - they often incorporate personal connections as the guarantee for quality, trust and organic qualification in the system. They provide opportunities for small farmers to produce and sell local, high-quality goods directly; and they provide consumers easy access to delicious, mostly ecologically-produced local goods (Réthy \& Dezsény, 2013).

In this paper, the hypothesis which will be tested is that community supported agriculture has probably several market problems yet. The most expected problem effect relates to the inadequate role of CSA organizations in agricultural markets.

\section{LITERATURE OVERVIEW}

SFSC is new or improved (with maximum one intermediary) sales method in the cooperation of agricultural producers, that is becoming a regular sales form of the members as time goes by (Reszketö, 2015). The term of short food supply chain covers a board range of marketing/supply channels. Generally, small geographical, social and cultural distance between producers and consumers is typical, and demand for environmentally friendly production methods is often also an important aspect (Benedek, 2014). In general, a food supply chain can be defined as "short" when it is characterized by short distance or few (even no) intermediaries between farmer/food producer and consumer. It works with maximum 1 intermediary, but strictly in non-profit way. It is possible for the producers to appoint or delegate a market organizer, too. 
Moreover, the Joint Research Centre of the European Commission created a common definition of SFSCs, based on several seminal studies in the topic: "The foods involved are identified by, and traceable to a farmer. The number of intermediaries between farmer and consumer should be 'minimal' or ideally nil" (Santini \& y Paloma, 2013).

The local food system is based on: more transparent and traceable food chains, wider range of producers - reduced intermediaries, "closer" relationship between producers and consumers, increased flexibility and adaptability to market changes (the adaptation capability to new situations and consumer needs is high). SFSC has many aspects of advantages, good examples on how SFSCs have increased sustainability in all dimensions: environmental, social, health and wellbeing, and - last but not least - in economic field. Therefore, SFSCs can act as a driver of change and a method to increase sustainability, trust, equality and growth in agricultural, food, business, social, health and rural policy areas. A SFSC can also be a vital element in building healthy local economies (Galli \& Brunori, 2013).

As part and parcel of SFSC system, the idea of community supported agriculture was first formulated in Japan in the 1960s and 1970s, as a solution to the growing industrialization of agriculture and food supply chains. The Japanese name of this producer-consumer system was "teikei", which means "food labeled with the face of the farmer". Producers involved in the system could be sure that their products are sold at a good price, while consumers could trust the quality of the goods purchased (Hayes \& Milánkovics, 2001). CSA is an alternative foodproducing network, a model of agricultural production and product distribution:

- It is based on the community with common interest of small farmers and consumers undertaking the risks of the production together and sharing the profits;

- The aim is to produce high-quality (mostly ecological) food for a local community in a risksharing membership/marketing structure.

These systems provide livelihood and plan ahead for hundreds of small farmers with the opportunity of direct sales, in a macroeconomic environment that is unfavorable for small family businesses. The essence of this method is direct relationship between the producers and customers and the trust based on this personal relation. In this relationship, the seller and the buyer do not have opposite interests; in fact, they are allies (Sokszínü Vidék, 2013). CSA systems have become increasingly important in food supply chains in the western part of Europe and North America in recent decades. Such initiatives started and spread in the 1980s in the US and Canada. Switzerland was the first European country to form CSA organizations (the first swiss CSA system was founded in 1978), while the first initiative in Germany was launched in 
1988. These groups also carried out educational activities and there were also some who gave job opportunities to disadvantaged or disabled workers.

CSA could be of particular importance for the agriculture of Central-Eastern European countries, where agriculture is still an important sector of production. Despite the different political and economic contexts, the development of this area is very similar to the processes occurring in Western Europe: the size of farms has increased, the production processes have become more and more intense, which caused the industrialization of agriculture. These changes and the structural transformation of the sector made the life of agricultural workers hard or even impossible. CSA could be a solution for their yet unsolved problems in today's environment, as they provide important social, economic and environmental advantages for both rural and urban communities (Murdoch, Wilson, \& Parrott, 2002).

\section{The situation of CSA in Hungary and in the Western Transdanubia region}

The alternative sales methods of CSA could address the problems of small-scale organic farmers who are struggling to access the market, as it puts emphasis on local food products, environmentally-friendly production methods and sustainable farming instead of global processes. CSA is able to help the development of food self-determination, as they make the supply of food more transparent, guarantee farmers their livelihood and promote knowledge about healthy lifestyles and healthy nutrition. CSA can also play a prominent role in preserving agricultural diversity and locally adapted knowledge and methods, for example by recycling and restoring landscape varieties. The environmental sustainability of CSA is promoted by more environmentally friendly production methods, the decreasing quantity of packaging material and the shorter transport distances (Réthy \& Dezsény, 2013). CSA is primarily targeting people who are wealthier than average, are more responsive to healthy nutrition and are environmentally sensitive. As CSA is widely spread in France, families with average income are more and more willing to join community supported agriculture. A similar dynamic development is yet to happen in Hungary, but it could be reasonable to promote the concept that has been backed by governmental attitudes: the formation and support of CSA organizations is part of the 2014-2020 Rural Development Program (in Short Supply Chain Thematic Subprogram) (Reszkető, 2015).

There is a growing demand for shortening the global food supply chain in more and more social groups in Hungary. The first CSA initiative was launched in 1999 under the name of “Open Garden" based on Anglo-Saxon example (Vadovics \& Hayes, 2007). The initiative was 
launched to promote sustainable food systems and to find alternative distribution channels. The currently operating Hungarian CSA systems were mostly influenced by the French AMAP movement (Alliance for Peasant Farming). The first CSA in France was established relatively late, in 2001; all the same the success of the model is apparent considering that there were 1600 communities in the country in 2012. In Hungary, the Association of Conscious Customers has played an indisputable role in the promotion of the French example: they organized several lectures, workshops and other events on the subject. These events helped CSA to gain media attention.

The number of community supported (shared) farms and subscription (box) systems is around 23 recently, although many new CSA systems are about to form. Within the Western Transdanubia region the Vegetable Community of Dunasziget is the prominent participant. The number of buying groups was 13 in 2018, almost exclusively in big cities (Budapest, Szeged, Miskolc, Debrecen) and in the agglomeration of Budapest, although in the examined region, such a community in Mosonmagyaróvár, called Szigetközi Szatyor Közösség (Wisket Community of Szigetköz) exist (Tudatos Vásárlók Egyesülete, 2018).

\section{Possible forms and grouping of CSA}

It should be emphasized that CSA also reflects a mentality, which has several forms of realization. It's essential that the core principles must be adapted to the social, economic and environmental conditions. The most common CSA systems are formed the following ways based on the degree of integration, from most to last (Fig. 1):

Community supported (shared) farms, where customers buy "shares": they pay for part of the harvest in advance and the farmers deliver them the products in return.

Subscription systems, in which farmers or a group of farmers and customers form a union and enter a contract. Farmers deliver fresh products regularly, usually once a week to consumers, who commit themselves to become permanent customers and pay for the goods.

Box systems, which are similar although a more flexible form of subscription systems. They allow customers to make orders without commitment when they need products, while farmers deliver the goods to previously formed distribution points (collection points).

Buying groups, where several local farmers, an NGO or a small community of customers organize a distribution and delivery system (either door-to-door or to distribution points) for locally or regionally produced goods of small farmers. Customer communities show a great deal of variety and flexibility depending on how they operate and what kind of products they are dealing with. 
Farmers' markets, that are (not exclusively) organized by a group of local farmers and where residents are able to buy fresh, local products directly from the farmers. (Vadovics \& Hayes, 2007; Réthy \& Dezsény, 2013)

Figure 1 Local food distribution systems according to the level of consumer's commitment

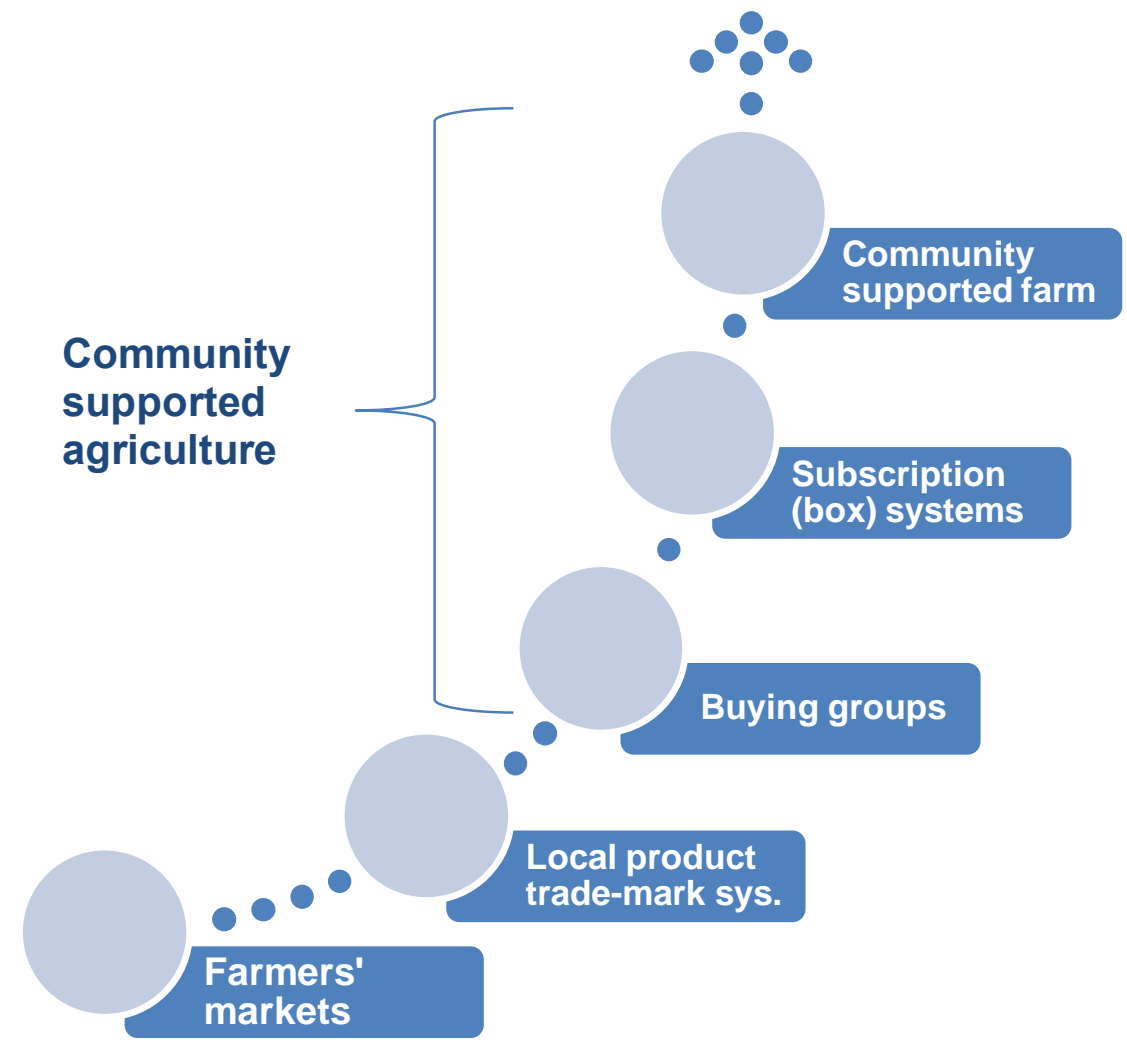

Source: own construction based on Vadovics and Hayes (2007), Réthy and Dezsény (2013)

The organizational structure of CSA systems can vary, we can found primary producers, sub-contractors, companies and NGOs among the producers. For producers in shared farms, CSA is the only way of selling, the other types also deliver they products and go on the market with them. Fair pricing is essential for CSA, as the main goal is to maintain farms. Prices have to cover production costs and provide livelihood for producers, all the while giving opportunity to set up reserves. On the whole, the most significant goals and effects of CSA system are:

- To offer an environment protection focused, sustainable alternative for agriculture;

- To provide more workplaces and livelihood opportunities for rural people;

- To preserve traditional production processes;

- To maintain a higher level of the diversity of species;

- To preserve the traditional landscape;

- To provide transparent and fair pricing and production processes. 
For local communities, the preservation of agricultural diversity is closely linked to commitment to environmental protection and landscape management. This is accompanied by the need to reduce the risks to climate change. They live and manage in a way that respects environment while maintains diversity at its maximum. They put emphasis on the application of agri-environmental methods and the re-naturalization of production methods, in which human interacts with nature. The initiatives active in the preservation of agricultural diversity contribute to the boost of the local economy, especially on rural areas and create new jobs. In addition to traditional producing activities, other opportunities for additional income can be incorporated into the system (Horváth, 2012).

\section{MATERIAL AND METHODS}

In this paper, a problem/objective tree analysis in connection with CSA was carried out by the colleagues of Széchenyi István University, Faculty of Agricultural and Food Sciences. For this study, a range of problems was considered, as result, the core problem was determined. In addition, causes and effects of forthcoming, listed problems were analyzed, which we depicted with a problem tree structure. The problem tree shows the negative aspects of the current situation, while the analysis of objectives points out to the positive aspects of the desirable future situation. The process includes the redrafting of problems in the form of goals, so the objective tree is basically mirror image problem tree. The cause and effect relation is replaced with the relation between assets and outcomes.

The focus of the survey and the subsequent study was conducted at the end of 2015 and early 2016 on the evaluation of the situation of regional and in some aspects domestic CSA, the viability and validity of CSA-based farms. The analysis of the Western Transdanubia region (Györ-Moson-Sopron, Zala and Vas county) was conducted with the involvement of the CSA organizations of the region with almost 40 farmers (Szigetközi Szatyor Közösség, Pannon Helyi Termék Klaszter, Zala Termálvölgye Egyesület) and the consumers connected to these organizations. The consumers were asked to fill out an online survey, while questionnaires were completed on the producer side by personal inquiries. The intermediary level (as an optional, not compulsory part of the system) were assessed based on existing regulatory framework and available statistical data. While processing the results, the number of evaluable surveys for customers is $n=103$, for producers it is $n=32$. Simple statistical analysis was used to present the problem structure of this issue, whereas the conclusions of problem tree analysis enhanced setting up the objective tree. 


\section{RESULTS}

Concerning farmers, the number of older workers is high, just like in the case of traditional agricultural producers. More than $58 \%$ of the respondents were over the age of 45 . Obviously, they have been operating their farms longer than their younger colleagues. The average operating time of 17 years suggests that this age group started the business relatively late, over the age of 40, just like younger people in this field of work. The employment of external labor is generally not typical. Apart from family members, they usually employ only one or two persons - either permanently and occasionally.

More than half of the respondents (55\%) use conventional, traditional production methods, and only $10 \%$ of them use organic farming. This special method is characteristic only for fruit farmers and mixed (fruit and vegetable) farmers. Nearly half of the respondents are working with products of animal origin, while the other half is working with products of plant origin. All pig holdings sell not only processed products, but also live animals - almost in the same proportion. When it comes to fruits, $1 / 3$ of the farmers sells only fresh fruits, $1 / 3$ of them sells only some kind of fruit products (jam, syrup and juices) and 1/3 of them sell a mixed palette (fresh and preparations). Regarding vegetables, $50 \%$ of the products are fresh and $50 \%$ of them are processed.

There is a significant spread in the size of territory both among all the farmers and between the representatives of different product groups. Honey producers do not have any land and the same goes for almost $50 \%$ of producers of animal origin products. Relating to farmed land, $52 \%$ of farmers own their own land, $24 \%$ own a large part of their land (50-100\%), while $1 \%$ of them does not own any land.

When enquires were made concerning distribution channels, none of the farmers mentioned sales from automatic vending machines or selling their products for hypermarkets and discount stores. Only one primary farmer of products of animal origin has resort to the meditator role of Producer Sales Organizations (PSOs). The most commonly used distribution channels are the farmers' market (91\%), the traditional market (69\%) and the direct on-farm sales (72\%). Almost one third of farmers are forced to find new markets more than $50 \mathrm{~km}$ away from their location and only about a tenth of them can sell their product locally (within $5 \mathrm{~km}$ range). The producers of animal products sell their products in a relatively small distance from their location (within $25 \mathrm{~km}$ range). The main reason is the transportability and perishability of their products. Honey producers and fruit farmers usually deliver their products to a larger distance (50-100 km).

Concerning consumer side, almost $60 \%$ of them are between the age of 25 and 44 . Most of them $(73 \%)$ are highly educated, their lowest level of education is high-school graduation. The 
average net income per capita is over $80,000 \mathrm{HUF}$ for the $3 / 4$ of the respondents, and they usually spend 15,000 HUF from this for local products, although there is a significant spread $(\mathrm{CV}=90 \%)$. The amounts of money a family spends on these local products vary from 2,000 HUF to 80,000 HUF in a month. It is clear from the analysis that the income of families does not influence their habits of consuming local products. $24 \%$ of the respondent families eat local products daily, while $42 \%$ of them eat these products more than once a week. The most popular products among consumers are vegetables and fruits. More than half of the customers also purchases meat, dairy products and honey. The market of other products (bakers' wares, oilseeds, wine, spirits, dry pasta, etc.) is not significant yet, as there are only a few participants both from the side of demand and supply.

Consumers purchase their products from traditional and farmers' markets. Although in a smaller proportion, but they also buy their products directly from the farmers, the greengrocers or with a special "take it yourself" offer. They do not usually purchase these products from hypermarkets, shop chains and discounts. The home delivery, vending machines and moving shops are not significant either. Almost a quarter of the respondents distinguish and take part of a consumer community. The two other forms of CSA, shared farms and subscription systems, are much less preferred (only 3-3\% of the respondents). One of the possible reasons for this is that only a small segment of customers are aware of CSA. Another reason might be the special structure of this agricultural method. As most of these farms own a fix group of customers for at least one year in advance, only a limited number of customers can be a part of these organizations. If they do not extend capacity, entering is only possible through replacement of members, thus only if a member decided to quit the organization.

In the last phase of the survey questions were asked about the possible problems occurring while purchasing local products. The results showed a significant spread between the answers. The opinion of consumers ranges significantly from the approach to different problems. Viewing the average of the answers of respondents, the average rate of factors odoes not exceed the medium level (3), this means that customers do not experience any of the factors - farms are hard to access, the purchase of local products is time consuming, limited variety of products, high prices, lack of information - most often when they purchase local products. Respondents think that lower level of enjoyment and unfavorable packaging are the least significant problems.

With the scrutiny and evaluation of the problems carried out during the analysis of the present survey the factor with the biggest impact was determined, i.e. the core problem: the market power of CSA organizations is insufficient. It is believed, that changing the attitude of stakeholders is inevitable to solve this problem. Following the analysis of problems, issues 
concerning the different stakeholders (consumers, intermediator organizations and producers) have been outlined in a problem tree. (Fig. 2)

Figure 2 Problem tree structure

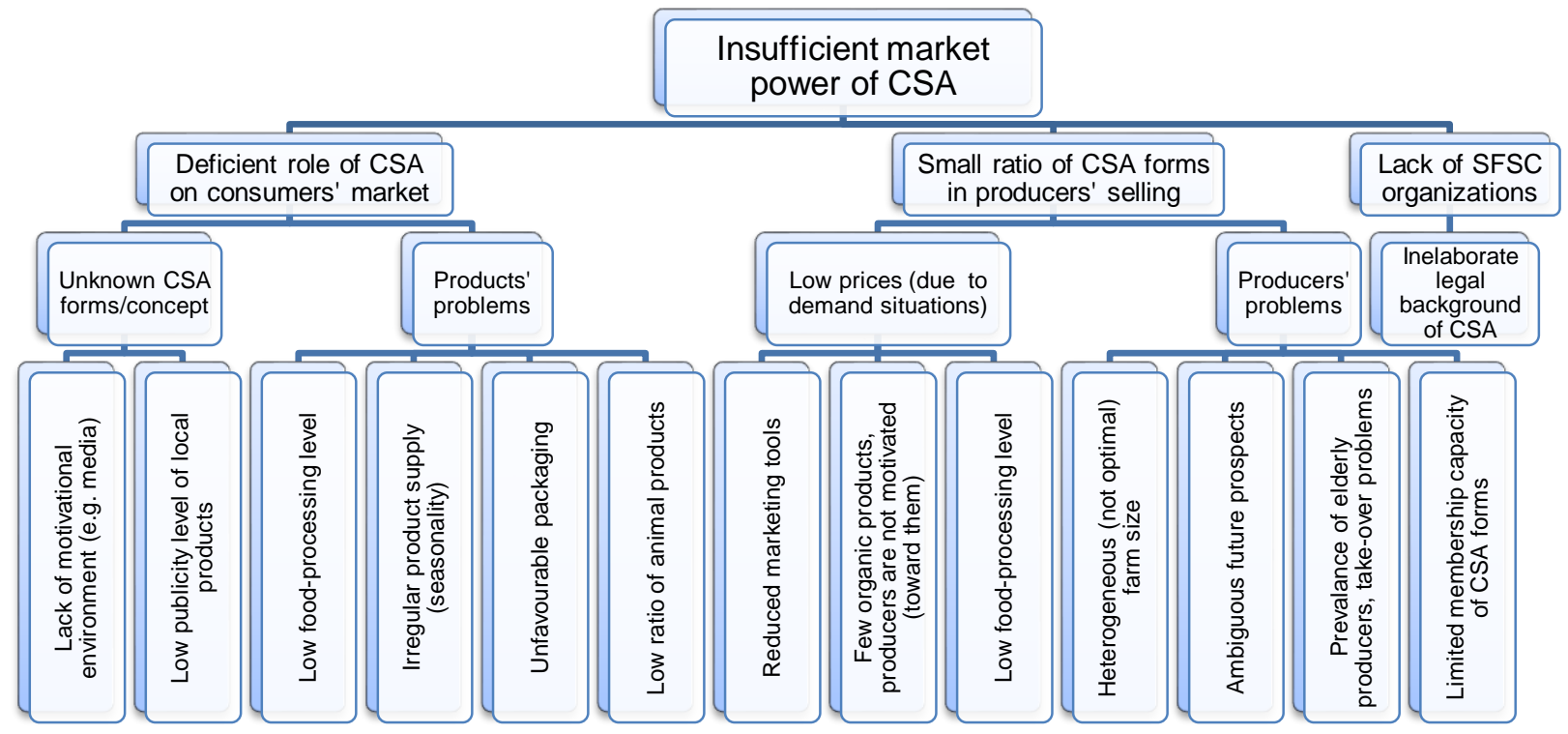

Source: own construction

Studying the problem tree, the answer to the core problem could be the appointment of a long-term, strategic goal: to increase the market power of CSA organizations. To achieve this, it is crucial to increase the motivational level of stakeholders. The answers and solution proposals to the problems of the different levels (consumers, intermediaries, and producers) of stakeholders can be seen in figure 3 concerning the objective tree.

Figure 3 Objective tree structure

Increase of the market power of CSA

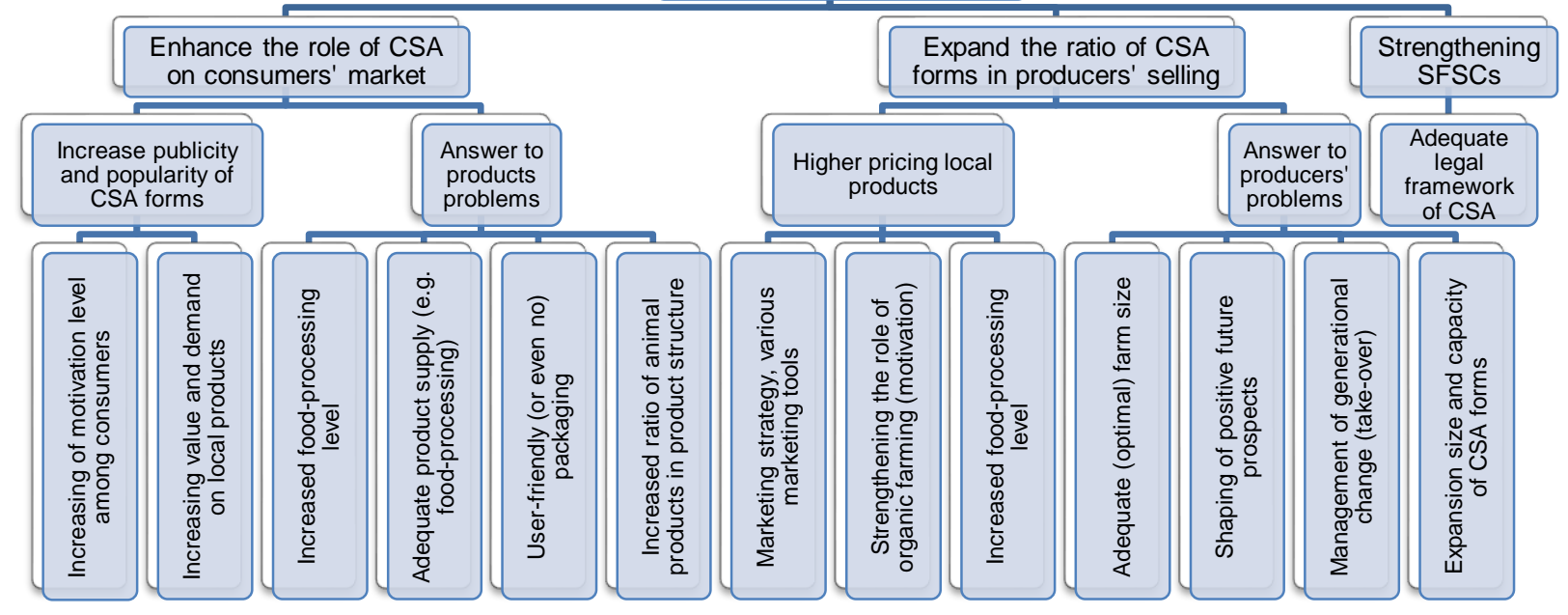

Source: own construction 
The methods and tools can be applied to achieve the desired effects depending on the nature of the problem - that is general or specific - and the financial opportunities or restrictive conditions.

Applicable tools on consumer level:

- to increase popularity: open gardens, family events, workshops, involvement of educational and research institutions, dissemination of results;

- $\quad$ state grants for food-processing investments;

- to develop and implement sources of support for organizing and making CSA forms more popular;

- to increase motivation level: open gardens, family programs, "farmer-wellness", workshops, involve educational and research institutions, disseminate results;

- to design "local product trademarks" for certain product lines, introduce quality assurance systems, develop regulatory systems (legislative frameworks);

- to ensure adequate product supply and packaging: ensure the requirements of storage, processing and packaging, investment grants.

Tools for intermediary organizations:

- to provide adequate, supportive legislation;

- to disseminate knowledge, promote CSA organizations, expand capacity and product scope;

- to utilize support possibilities of the Rural Development Program (2014-2020).

Tools available for producers:

- to integrate the topic into public and higher education, promote a multilevel background support for generational change;

- to facilitate conditions for small livestock farming and supply, create an infrastructure background (subsidies), raise and/or diversify livestock;

- to support policy, favorable credit structures, adequate land policy and operational control frameworks;

- to boost the involvement of professional organizations, consultancy and further training (promotion of organic farming);

- to simplify small-scale taxation and administrative simplification, reduce taxes and contributions to create a positive vision;

- to increase the motivation of producers through professional forums, workshops and appropriate support policies; 
- to increase the degree of processing (added value) to increase the price level of local products, increase the product range, use efficient markers;

- to provide vocational training and further training in marketing, through the dimension of strategy.

\section{CONCLUSION}

In Hungary, agriculture has significant importance due to the natural conditions of the country. It plays major role both in employment, in the maintenance of the rural population and in internal and external trade. This is especially true for rural areas, where many of the CSA solutions can be important in meeting these goals. Taking the economic considerations into account, we attach decisive importance to the role of the state in the promotion of community supported agriculture, at least in the first phase. That is why it is considered to be highly useful for all stakeholders that the Short Supply Chain Thematic Subprogram is included in the Rural Development Program.

The exploration of systemic problems of community agriculture is essential to support the spread of CSA, to eliminate the factors that limit its effectiveness and to inspect ways to increasing the number of stakeholders. This study offers some important insights into this field of problems. The tested hypothesis, namely the probable market problems of CSA gained verification. Among them, the most significant problem was actually related to the insufficient role of CSA organizations in agricultural markets.

The core problem raised in the analysis of the Western Transdanubia region, namely the boost of the market power of CSA organizations at the top of the objective tree, is possible to be solved using the tools proposed by the study together with their allocation to a coherent strategic system.

\section{Acknowledgement}

This research was supported by EFOP-3.6.1-16-2016-00017 "Initiatives to establish a new source of researchers and graduates, and development of knowledge and technological transfer"

\section{REFERENCES}

Benedek, Z. (2014). The impacts of short food supply chains. A review of the international literature supplemented by Hungarian experience. Discussion Papers MT-DP - 2014/8, 4. Budapest: Hungarian Academy of Science Centre for Economic and Regional Studies. Santini, F., \& y Paloma, S. G. (Eds.) (2013). Short Food Supply Chains and Local Food Systems in the EU. A State of Play of their Socio-Economic Characteristics. European Commission Joint Research Centre, Scientific and Policy Reports, Luxembourg: Publications Office of the European Union. 154. 
Galli, F., \& Brunori, G. (Eds.) (2013). Short Food Supply Chains as drivers of sustainable development. Evidence Document. Document developed in the framework of the FP7 project Foodlinks (GA No. 265287). Laboratorio di studi rurali Sismondi, ISBN 978-8890896-01-9., 10.

Horváth, G. (2012). Közösségi Mezögazdálkodás - Legyél a részese! (Community Supported Agriculture - Be part of it!). Budapest: Tudatos Vásárlók Egyesülete. [Pdf]. Retrieved from:

https://tudatosvasarlo.hu/sites/tudatosvasarlo.hu/files/kozossegi_mezogazdalkodas_legy _a_reszese_0.pdf

Kajner, P. (Ed.) (2007). Gazda(g)ságunk újrafelfedezése. Fenntartható vidéki gazdaságfejlesztés elméletben és gyakorlatban. (Rediscovering our economy/richness. Sustainable rural economic development in theory and in practice). Budapest: L'Harmattan Kiadó, 64.

Hayes, M., \& Milánkovics, K. (2001). Community Supported Agriculture (CSA): a farmers' manual: how to start up and run a CSA. Gödöllö: Nyitott Kert Alapítvány, 87.

Murdoch, J., Wilson, N., \& Parrott, N. (2002). Spatializing Quality: Regional Protection and the Alternative Geography of Food. European Urban and Regional Studies, 9(3), 241261.

Reszkető, T. (2015). Vidékfejlesztési program kézikönyv. (Rural Development Program Handbook). Budapest: Nemzeti Agrárgazdasági Kamara, 78-79.

Réthy, K., \& Dezsény, Z. (2013). Közösség által támogatott mezögazdaság. (Community Supported Agriculture). Budapest: Ökológiai Mezőgazdasági Kutatóintézet (Research Institute of Organic Agriculture) Közhasznú Nonprofit Kft. (ÖMKi), 4-7.

Sokszínű Vidék (2013). Hazánkban is terjed a közösségi mezögazdálkodás (Community agriculture is also spreading in our country) [Html]. Retrieved from: http://www.sokszinuvidek.hu/index.php/eletmod/2106-Haz\%C3\%A1nkban-is-terjed-ak\%C3\%B6z\%C3\%B6ss\%C3\%A9gi-mez\%C5\%91gazd\%C3\%A1lkod\%C3\%A1s

Tudatos Vásárlók Egyesülete adatbázisa (2018). (Association of Conscious Consumers data base). Bemutatkozik a Tudatos Vásárlók Egyesülete (Introducing the Association of Conscious Consumers) [Html]. Retrieved from: http://tudatosvasarlo.hu/tve

Vadovics, E., \& Hayes, M. (2007). Nyitott Kert - egy helyi bioélelmiszer-hálózat Magyarországon. (Open Garden - a local organic food network in Hungary). Ökológia, gazdálkodás, társadalom (ÖKO), 15(1-4), 104-124. 